\title{
WYCHOWAWCZA WARTOŚĆ NAUCZANIA BŁ. STEFANA KARDYNAŁA WYSZYŃSKIEGO O RODZINIE I NARODZIE
}

Streszczenie: Błogosławiony kardynał stracił matkę w wieku dziewięciu lat, od tego czasu jego Matką stała się Ojczyzna, dla której służył, którą kochał i o którą walczył - walczył miłością do każdego bliźniego i o każdego bliźniego. Doświadczył okrucieństw wojny i reżimu sowieckiego, jego ukochana Ojczyzna pozbawiła Go wolności, a on dla niej ułożył Śluby Jasnogórskie, które stały się pierwszym krokiem na drodze wyzwolenia Ojczyzny, Narodu i polskiej rodziny, dla której kardynał Wyszyński był niekwestionowanym Ojcem.

Słowa kluczowe: Stefan kardynał Wyszyński, rodzina, Naród, matka, ojciec, wychowanie, wiara.

\section{Wstęp}

Współczesny człowiek, zapracowany, biegnący za pozornym szczęściem, przesycony napływem informacji spowodowanym wszechobecnym światem środków masowego przekazu. Żyjący w rodzinie, ale często nieposiadający dostatecznej informacji na temat jej ważnej roli i zadań, jakie przed nią stoją, powinien zatrzymać się w tej pogoni i na nowo odkryć przesłanie człowieka, dla którego troska o właściwą rodzinę, jej kształt wypływała z jego pasterskiej odpowiedzialności i głębokiego patriotyzmu, a te wartości podpowiadały mu, że bez rodziny nie ma przyszłości Narodu. Prymas Tysiąclecia Stefan kardynał Wyszyński wiedział, że człowiek formowany jest przez dwie najważniejsze i naturalne dla niego wspólnoty, mianowicie przez rodzinę i Naród.

* Ks. mgr lic. Jerzy Andrzej Danecki, proboszcz parafii pw. Matki Bożej Dobrej Rady w Wólce Mińskiej, absolwent PWTW w Warszawie, Szkoły Wyższej im. Pawła Włodkowica w Płocku, Wyższej Szkoły Menadżerskiej w Warszawie; e-mail: jerzy.danecki@wp.pl. 


\section{Rodzina i Naród}

Zdzisław Struzik przywołuje słowa Prymasa: „Rodzina i Naród - pisał Prymas Wyszyński - to nie są instytucje, to są organizmy żywe, mające swoją własną dynamikę i przejawy biologicznego bytowania. Poza nimi wszystkie inne formy bytowania, takie jak państwo, rząd, partia - mają wymiar instytucji. Naród i rodzina muszą istnieć, a tamte instytucje mogą istnieć lub nie" (Wyszyński 2007d, s. 15). Rodzina dla kardynała Wyszyńskiego była największą siłą Narodu i gwarantowała jego trwałość i przetrwanie. Prymas często powtarzał, że bez mocnej, czystej, zwartej, zespolonej rodziny, nie ma Narodu. Dlatego tworząc naród, trzeba pracować nad umocnieniem i zjednoczeniem każdej rodziny (Wyszyński 2007, s. 16). Naród jest rodziną rodzin. I tylko na tym fundamencie może się spokojnie rozwijać życie osobiste, rodzinne, religijne, społeczne, zawodowe, narodowe i państwowe (Struzik 2010, s. 107). Nauczanie kardynała było mocno naznaczone definiowaniem modelu wychowania - przypomina Struzik - co przy zachowaniu tradycji rodziny chrześcijańskiej wymaga współpracy rodziny, Narodu, państwa i Kościoła. Rodzina jest w procesie wychowania społecznością pierwszą i podstawową, ale nie jedyną. Inne społeczności, takie jak Naród, państwo, szkoła, Kościół, również mają znaczące oddziaływanie wychowawcze, lecz ich charakter wobec rodziny jest pomocniczy i służebny. Środowiska te mają pomagać rodzinie w jej zadaniach i funkcjach, a nie mogą jej zastępować czy wyręczać. Prawa rodziców do wychowania dzieci zgodnie $\mathrm{z}$ własnymi przekonaniami nie może odebrać żadna władza ani społeczność. Prawa rodziny wynikają bowiem z prawa naturalnego i ze związku krwi (Struzik 2010, s. 107).

W myśl Wyszyńskiego naród, aby miał duchową siłę, musi dążyć „do obrony życia nienarodzonych, do wierności ślubom małżeńskim, do podniesienia moralności współżycia małżeńskiego, do cnoty męstwa i wstrzemięźliwości, do czujności nad wychowaniem moralnym i religijnym młodzieży i dziatwy, aby z rodzin katolickich nie wyrastali ateiści i poganie" (Wyszyński 2007e, s. 69-70).

Między rodziną i Narodem a państwem istnieje zasadnicza i niezbędna relacja. Posiada ona - w nauczaniu kardynała Wyszyńskiego - charakter społecznej koligacji: zdrowa biologicznie i moralnie rodzina przedłuża byt Narodu, zabezpiecza jego tożsamość i dziejowy rozwój. Z kolei naród i państwo w trosce o zabezpieczenie własnego bytu dążą do podtrzymywania należnej pozycji rodziny w społeczeństwie. Dla Prymasa Naród to rodzina rodzin. „Słusznie mówi się, że naród jest rodziną rodzin, bo narodowi, państwu i Kościołowi najwięcej dają rodziny, rodzice, mąż i żona” (Wyszyński 2007e, s. 77). Stanowi o „być albo nie być” społeczeństwa. „W jedności rodziny i jej umocnieniu widzimy wzmocnienie jedności Narodu. Naród składa się z rodzin i dlatego każdy, kto chce umocnienia Narodu, musi pracować nad umocnieniem rodziny" (Wyszyński 2007e, s. 300). Jasnogórskie Śluby Narodu wprowadzone przez Prymasa Wyszyńskiego wprost nawoływały do zrozumienia i zastosowania podstawowych zasad obrony Narodu przez obronę 
rodziny. Prymasowskie spojrzenie na Naród sięgało do wartości duchowych człowieka. Społeczność to jedność duchowa, „jedność serc” (Wyszyński 2007b, s. 300).

Wyszyński nie obawiał się publicznego upominania narodu i polskich rodzin poprzez wytykanie im takich zachowań, jakie odbierają godność człowieka z jednej strony, a wspierają działania komunistyczne z drugiej. „W marnotrawstwie i w pijaństwie będziemy widzieli niszczenie naszych sił fizycznych i duchowych, naszych zasobów materialnych, majątku osobistego i narodowego, zwłaszcza lepszego bytu naszych rodzin i dzieci" (Wyszyński 1995, s. 84).

Poważnym zagrożeniem, tak kiedyś i dziś, dla rodziny i dla narodu, jest plaga narastającego pijaństwa. Nadużywanie alkoholu kiedyś było tłumaczone brakiem właściwego poziomu życia, dziś dobrego poziomu życia. Nędzne zarobki nie pozwalały rodzinom na godziwe życie i nie rokowały możliwości jakiegokolwiek oszczędzania. $Z$ takim rozumowaniem nie zgadzał się Prymas Wyszyński. Uważał, że nie można jednego nieszczęścia pogłębiać jeszcze gorszym. „Te dzieci, i te matki wyblakłe, wychudłe, wynędzniałe. Tak wygląda nasza ojczyzna i to jest wielki ból, bo mogłaby wyglądać inaczej, lepiej, pomimo ciężkiej pracy tego narodu" (Wyszyński 1999c, s. 327-328).

Jak zauważa Struzik - poprzez swoje nauczanie Prymas Wyszyński sformułował coś na kształt programu prorodzinnego, który zawierał typowo społeczno-ekonomiczne postulaty: poprawa płacy ojców, wprowadzenie dodatku wychowawczego dla matek, dowartościowanie ekonomiczne rodziny dla celów opiekuńczych wobec dzieci, zerwania z wyzyskiwaniem ludzi pracy (Struzik 2010, s. 110). Prymas Wyszyński tak mawiał przed obrazem Matki Bożej Jasnogórskiej: „To jest wielki program narodowy, wypowiedziany u stóp Jasnej Góry: umacniać jedność Narodu, przez umacnianie jedności w rodzinie. A jedność serc! - Gdzież ona się bardziej wychowuje, jak nie w rodzinie, gdzie z jedności serc męża i żony rodzi się jedność całej rodziny. Na przykładzie wierności obojga, pielęgnuje się z kolei wierność dzieci wobec rodziców i rodzeństwa między sobą" (Wyszyński 2007b, s. 300).

Obrona rodziny, a co za tym idzie obrona Narodu, polega także na odczytywaniu w życiu rodzinnym naturalnej, przyrodzonej wartości, to znaczy jej naturalnej skłonności do radości. Prymas widział tę psychologiczną wartość, która jest niezmiernie ważna i nieustannie powinna być eksponowana i pielęgnowana, bo człowiek, mąż i żona oraz dzieci, bez tej radości tracą sens poniesionych nieustannych wysiłków, aby trwać w zjednoczonej rodzinie. Ta naturalna radość staje się fundamentem trwania i pokonywania wszelkich trudności pojawiających się w życiu. „Trudności życia, kłopoty, męki i bóle, niezgodne usposobienia czy też wady lub nałogi w życiu nabyte, taki czy inny ustrój państwa lub życia gospodarczego, nie odbierze wam radości. Bo największą radością dla was, matki i dla was, ojcowie, po ciężkim trudzie i męce pracy codziennej, jest wasza rodzina” (Wyszyński 1999a, s. 132). Ratunkiem dla Narodu jest katolicka rodzina. „Obowiązkiem waszym jest wychować rodzinę $\mathrm{w}$ wierności obyczajowi ojczystemu, jak również w wierności samej rodzinie. Chodzi o to, aby ognisko życia rodzinnego jak najbardziej utrzymać, 
uświęcić, aby rodzina była miejscem szacunku i miłości męża dla żony i dzieci, żony dla męża i dzieci, rodziców dla dzieci, dzieci dla rodziców" (Wyszyński 1999f, s. 355).

Prymasowi towarzyszyła zasada, iż kto chce władać państwem, Narodem, Kościołem czy rodziną, musi naprzód nauczyć się władać sobą. „Umiemy wymagać od innych, zapominając często, że dobra, których pragniemy, rodzą się nie gdzie indziej, tylko w nas, w duszy i sercu człowieka. Tym większe mamy prawo stawiać wymagania innym, im bardziej sami je urzeczywistnimy" (Wyszyński 2007g, s. 312-313). Wyszyński przypominał: „My wszyscy, najmilsze dzieci, mieszkańcy jednego domu, jednego miasta, narodu, jednej części świata, globu całego, jesteśmy przede wszystkim Bożymi dziećmi" (Wyszyński 2007h, s. 14). Innymi słowy - jak podkreślał i przestrzegał Prymas - rozumienie narodu bez Boga, bez rzeczywistości nadprzyrodzonej, jest rozumieniem niepełnym i dlatego prędzej czy później musi się obrócić przeciwko samemu narodowi (Lewandowski 1983, s. 30-31).

\section{Małżeństwo i rodzicielstwo}

Ogniwem spajającym wysiłki w pogłębianiu życia duchowego małżonków, wynikające ze świadomości własnego chrztu, staje się decyzja o włączeniu we wspólnotę wiernych własnego dziecka - stwierdza Adam Skreczko. Chrzest potomstwa to kontynuacja i nowy etap w przeżywaniu wiary rodziców (Skreczko 2006, s. 148), „(...) to naturalny, wypełniony łaską i kształcący moment w życiu rodziny, kiedy zaczyna ona swoją podróż do pełni chrześcijańskiego życia. Może ona wspólnie modlić się, uczyć, planować i stać się tym, co można nazwać rodziną chrzestną. Rodzina chrzestna jest rodziną, której prawdziwym Ojcem jest Bóg, której starszym bratem jest Jezus, i której źródłem życia jest Duch Boży. W rodzinie chrzestnej rodzice, chrzestni i dzieci znają Jezusa Chrystusa jako swojego Zbawiciela i wierzą, że On naprawdę żyje, a Jego droga jest najlepsza" (Libersat 1995, s. 40). Kardynał Stefan Wyszyński nauczał, że najpierw „Światłość Boża” ma płynąć w rodzinach, a dopiero potem zacznie udzielać się ona dzieciom. Rodzice powinni ją rozniecać. Powinni od samego początku życia swych dzieci pragnąć, aby ich potomstwo nowonarodzone jeszcze raz się narodziło, tym razem nie z ich krwi, ale z Ducha i wody (Wyszyński 1999g, s. 138). Kościół wzywa wszystkich rodziców chrześcijańskich i ochrzczone dzieci do najbliższej współpracy z kapłaństwem Chrystusowym. Tym samym pragnie, aby to właśnie rodzice, w sercach swoich dzieci, przygotowywali Lud Boży. Rodzice powinni pamiętać, że Lud Boży to nie tylko lud zrodzony z ciała, ale przede wszystkim z ducha (Wyszyński 1999h, s. 272). Rodzice powinni mieć też na uwadze, że ich dziecko przez chrzest staje się członkiem rodziny nadprzyrodzonej, którą jest „kościół, organizacja nadprzyrodzonej miłości” (Wyszyński 1962, s. 45). Poprzez to także ich dzieci, ochrzczone w imię Ojca i Syna, i Ducha Świętego, muszą teraz żyć według łaski, którą otrzymały podczas chrztu i - jak mówił kardynał Stefan Wyszyński - „tu się zaczyna praca wychowawcza rodziców” (Wyszyński 1999d, s. 22). 
Prymas Stefan Wyszyński w swych kazaniach podczas Wielkiej Nowenny Tysiąclecia nauczał wiernych również o sakramencie małżeństwa, o rodzinie, o zadaniach małżonków, a także o fundamentach wychowawczej funkcji rodziców. Kardynał Wyszyński bardzo klarownie i konsekwentnie wyrażał się o rodzinie katolickiej, uświęconej sakramentem małżeństwa. Przekazywał wiernym, jaka wspólnota osób najlepiej wpływa na wychowanie dziecka, iż jest nią rodzina, instytucja naturalna, utworzona przez związek kobiety i mężczyzny wraz z dziećmi zrodzonymi z tego związku. Podstawą rodziny jest małżeństwo oparte na obustronnej umowie, gdzie małżonkowie oddają się sobie w sposób wyłączny i stały w celu zrodzenia i wychowania dzieci. Prymas nauczał: „Ta instytucja naturalna została przez Zbawiciela podniesiona do nadprzyrodzonej godności sakramentu. Odtąd każdy związek małżeński między dwojgiem osób, naznaczonych stygmatem chrztu świętego, zawarty w sposób sakramentalny, staje się źródłem łaski i uświęcenia" (Wyszyński 1965, s. 102). Dzięki temu prawo rodziców do wychowania swych dzieci stało się jeszcze pełniejsze, to sam Chrystus powołuje rodziców do troski o chrześcijańskie wychowanie religijne swoich dzieci. Prawo naturalne rodziców zostało tym samym wzmocnione nadprzyrodzonym posłannictwem (Wyszyński 1963a, s. 235).

Prymas przypominał rodzicom, że przez sakramenty święte zarówno mąż, jak i żona mają Ojca w Niebie, który jest także Ojcem ich dzieci. Rodzina ludzka zatem z Boga poczęta „ma mieć Boga w swym łonie: musi dbać o to, by Bóg nie był tylko gościem, ale obywatelem i ojcem rodziny (Wyszyński 1961c, s. 226). Rodzice też powinni patrzeć na siebie nawzajem podobnie jak patrzą na Maryję - podtrzymującą, pielęgnującą, wspierającą, karmiącą Boże dzieci, jak stwierdza Adam Skreczko. W jednym ze swoich kazań kardynał mówił: „Ty, matko, i ty, ojcze, powołani przez sakrament małżeństwa do zaszczytnego życia rodzinnego, musicie również mieć w sobie tę postawę: "Oto ja Służebnica Pańska»" (Kukołowicz 1982, s. 2).

Ukazanie rodziców jako daru Bożego jest ważne, aby jeszcze bardziej potrafili docenić i cieszyć się z dobroci Boga Ojca, który pragnie całkowicie zbliżyć się do człowieka i jego drogi życia. Bóg Ojciec pragnie wręcz podzielić się z ludźmi swym życiem i ojcostwem. To On dał rodzicom taką moc, że życie, które przekazują swoim dzieciom, „trwać będzie w nieskończoność i już nigdy nie umrze” (Wyszyński 1961b, s. 202). Kardynał Wyszyński podczas kazania w Warszawie mówił: „Z Jego ojcostwa jest wszelkie ojcostwo na niebie i na ziemi i nie masz ojcostwa poza Nim! Jeżeli się więc objawia na ziemi życie i ojcostwo to zawsze jako uczestnictwo w życiu i ojcostwie Bożym. Jest to wyraz wielkiej miłości, dobroci i łaskawości najwyższej Ojca życia i wszelkiego ojcostwa" (Wyszyński 1963c, s. 4).

Zdaniem Adama Skreczko, przeżywanie komunii rodzinnej poprzez wzajemne relacje rodziców i dzieci w pełni ukazuje, że małżonkowie dopełniają swe rodzicielstwo ojcostwem i macierzyństwem duchowym poprzez wychowanie (Wojtyła 1986, s. 232). Wychowanie jest w tym samym stopniu płodne, co prokreacja biologiczna, ponieważ rodzi osobowość człowieka i wprowadza go w życie nadprzyrodzone. 


\section{Wychowanie do odpowiedzialnego ojcostwa i macierzyństwa}

Prymas Wyszyński wzywał ojców, aby wpatrywali się w ojcostwo Boga i odkrywali swe powołanie na nowo. Ma to być powołanie do „żywienia Boga w rodzinach”. Mówi, iż jak Bóg żywi rodziców „chlebem żywota”, tak ojcowie mają ten „chleb” podawać swoim dzieciom. Mówił też, że rodzice powinni mieć w swych dzieciach odrodzone Dzieci Boże. Nawoływał ojców, aby pamiętali, że oni dali synom ciało, ale ducha dał im Bóg. „Twój syn jest Bożym synem” - mówił kardynał - „Jego masz żywić" (Skreczko 2006, s. 155). Ojcostwo i nierozerwalne z nim posłannictwo wychowawcze to fragment rzeczywistości dosyć zaniedbany w dzisiejszym świecie, co w efekcie rodzi niedobre owoce - dopowiada Skreczko.

Troskliwe pełnienie obowiązku wychowania oznacza zaangażowanie, ofiarność i kompetencję. Ojciec nie może wymawiać się brakiem czasu czy odpowiedniego przygotowania. Nie może więc stronić od pracy wychowawczej, zostawiając ją żonie, ale jednocześnie nie powinien przywłaszczać sobie monopolu na wychowanie potomstwa (Mierzwiński 1996, s. 201).

W nauczaniu kardynała Wyszyńskiego szczególnie wysoka funkcja przyznawana jest macierzyństwu (Rosik 1991, s. 96-98). Szacunek dla macierzyństwa objawiał się u Prymasa wielką walką o obronę godności kobiety. Nie tylko kobiety-matki, aczkolwiek jej ranga jest najwyższa, ale kobiety w ogóle. „Boć macierzyństwo to jest - serce. Matka - to serce” (Wyszyński 1958, s. 180). „W każdym domu do kołyski nowonarodzonego dziecięcia przychodzi naprzód matka, a ojciec, choćby najlepszy, stoi z daleka i delikatnie podchodzi, by - nie przestraszyć. I do koleby ludzkości musiała naprzód przyjść Matka, by z wrodzoną delikatnością, łagodnością i dobrocią, oswoić niemowlę ludzkości, które zaczyna dopiero żyć” (Wyszyński 1960, s. 94). Już z tych słów wynika, że w powołaniu rodzicielskim - w nauczaniu Prymasa - różne role przypadają rodzicom. Jak widać, matka ma inne zadanie i predyspozycje, ojciec - inne.

Kardynał Wyszyński przypominał, że Maryja jest bliska matce, jako wzór macierzyńskiej miłości i wychowania dzieci Bożych (Wyszyński 1963b, s. 30). Staje się bliska poprzez swe macierzyństwo każdej matce. Kardynał Stefan Wyszyński apelował do rodziców, aby modlili się za swoje dzieci, wtedy to na pewno w każdej rodzinie, która naśladuje Świętą Rodzinę, zajaśnieje Boże światło. Dzięki temu rodzice będą mogli łatwiej pokonać trudy wychowania, jednak musi być w tym wszystkim modlitwa, uległość posłannictwu i powołaniu. W takiej rodzinie bardzo często pielęgnuje się powołanie (Wyszyński 1963b, s. 30).

Prymas Wyszyński nauczał rodziców o tym, jak ważne jest macierzyństwo Maryi w życiu małżeńskim i rodzinnym: „Chwała Jej Boskiego Macierzyństwa spływa na każde macierzyństwo. Boże Narodzenie ma olbrzymie znaczenie dla każdego narodzenia ludzkiego. Tajemnica Kolebki Betlejemskiej opromienia światłem każdą kołyskę. Dzieło życia Nazaretańskiego jest przez Maryję promienne w każdej rodzinie, która naśladuje Świętą Rodzinę" (Wyszyński 1960, s. 96). Dlatego tak 
bardzo zależało Prymasowi, aby rodzice zdali sobie sprawę z tego, jak cenne jest uświęcone małżeństwo. Kościół na przykładzie Maryi uczy wszystkie matki i ojców głębokiej czci i szacunku dla macierzyństwa, kryjącego w sobie nienarodzonego jeszcze człowieka. Nauka Kościóła uczy, że w pierwszym momencie kształtowania się nowego życia sam Bóg aktem stwórczym powołuje do bytu nowego człowieka nową duszę i powierza ją matce. Stąd też należy się wielki szacunek macierzyństwu i każdej kobiecie. Sam Bóg działa w człowieku. Macierzyństwo więc jest aktem świętym, jak nauczał Prymas (Wyszyński 1964, s. 94). Kardynał Wyszyński mówił: „Kościół ciągle zwraca oczy ku rodzinie, patrzy pod serce matki i w kolebkę życia rodzinnego. Ukazuje nam wzór Najświętszej Rodziny, bo wie, że rodzina - to kolebka życia, to szkoła miłości i najlepsza szkoła wychowania" (Wyszyński 1966, s. 350). Kardynał Stefan Wyszyński nauczał rodziców, mówiąc do nich, aby w trudach wychowania nie załamywali się, aby zwracali się ku Świętej Bożej Rodzicielce, i patrząc w Jej serce i życie, rozważali to, co dzieje się w ich rodzicielskich sercach i co jest zadaniem ich małżeńskiego i rodzicielskiego życia. Rozważanie życia Tej, która wzorowo wypełniła swoje zadanie - przekazanie życia Bogu-Człowiekowi, wpłynie poprawnie na rozwój ich powołania (Wyszyński 1999e, s. 349). Jak nauczał kardynał: „Historia Nazaretu ma się powtórzyć w każdym domu” (Wyszyński 2007c, s. 234). Aby to mogło się stać, daje jeszcze jedną wskazówkę, która jest może najważniejsza dla rodziców chcących po katolicku wychować swe dzieci. Ta wskazówka, ten drogowskaz, to Krzyż, który jest zawsze szczytowym ideałem wychowania i związane z nim hasło „Zwyciężać siebie” (Wyszyński 1959, s. 119).

Rodzina była ważna dla Prymasa, bo w niej widział zdrowy naród, a temat Narodu był szczególnie bliski kardynałowi. Świadczą o tym jego słowa: „W stosunku do mojej Ojczyzny zachowuję pełną cześć i miłość” (Wyszyński 1998, s. 13). Kardynał Wyszyński znał receptę na dobry Naród, mówił: „Związek z Ojczyzną kształtuje się przez wszystko: przez pierwsze słowa w ojczystym języku szeptane przez matkę nad kołyską dziecka i pierwsze słowa, które ono wypowiada: mama, tata, mamusia; przez pierwsze śpiewy, które słyszy w dzieciństwie, przez najbliższe otoczenie, z którym zapoznaje się, otwierając swe oczy na wielki Boży świat. Więź z ojczyzną pogłębia się przez otoczenie i zwyczaje rodzinne, przez wychowanie uspołeczniające, wiążące człowieka z szerszą społecznością" (Wyszyński 1998, s. 43). Na podstawie zacytowanych dotychczas wypowiedzi łatwo daje się zauważyć, jak ogromną rolę mają do wypełnienia rodzice polskich dzieci.

\section{Należna pomoc rodzinie}

Prymas Wyszyński poświęca wiele uwagi kwestii pomocy społecznej, na którą powinna liczyć rodzina. Zauważa, iż nie wszystkie rodziny mogą w pełni realizować swoje obowiązki. Przyczyną tego stanu rzeczy jest m.in. wielodzietność rodzin przy niskich zarobkach i braku własnych mieszkań - z czym i dziś mamy wiele trudności. Świadczy to o wielkiej niedoli rodziny, której z pomocą powinno 
przyjść społeczeństwo. Najskuteczniejsza pomoc to zagwarantowanie stanowisk pracy. Stosunki gospodarcze i społeczne w państwie powinny być ułożone tak, aby ojcowie mogli otrzymać wynagrodzenie za pracę w wysokości zapewniającej godny byt rodziny (Wyszyński 1946a, s. 3).

Zdaniem kardynała Wyszyńskiego, jeśli pomoc ze strony struktur państwa nie jest możliwa, trzeba wówczas odwoływać się do wspólnego wysiłku i przeciwdziałać istniejącemu stanowi rzeczy przez pomoc prywatną i publiczną (Wyszyński 1946a, s. 3). Działania charytatywne są bowiem jednym z przejawów realizacji społecznej nauki Kościoła. „Rodziny wielodzietne, trapione chorobami i nieszczęściami, wymagają pomocy i chrześcijańskiego miłosierdzia. Należy dobrowolnie ograniczać własne potrzeby, by tą drogą zdobywać środki dla pomocy bliźniemu, ratowania rodziny, życia dzieci i życia narodu. Ma to wynikać z prawd miłości bliźniego, życia wartościami ewangelicznymi, powinno być elementarnym obowiązkiem chrześcijanina, nie zaś tylko czynem" - stwierdza Waldemar Karasiński (Karasiński 2002, s. 343).

Kardynał Wyszyński zdawał sobie sprawę, że nawet najlepiej rozwinięta w społeczeństwie praca charytatywna nie jest w stanie zapobiec ubóstwu. Dlatego dalej mówi o tym, że przede wszystkim państwo ma obowiązek spieszenia z pomocą rodzinie, gdyż od tego zależy jej egzystencja. Dlatego powinno ono wykorzystać swą władzę ustawodawczą przy planowaniu budżetu i w ten sposób nieść pomoc najbiedniejszym. Wzywa państwo do wrażliwości społecznej, do wprowadzania zmian na lepsze. Wspólnocie rodzinnej nie wystarczy tylko pomoc materialna. Od państwa i Kościoła oczekuje się czegoś więcej, a mianowicie pomocy duchowej, moralnej i religijnej (Wyszyński 1946a, s. 3-4). Żadne przemiany nie będą skuteczne i błogosławione, jeśli nie będą podjęte $\mathrm{w}$ imię Boże i prowadzone zgodnie z Bogiem. Wyszyński nauczał o konieczności istnienia harmonii między ustawami państwowymi a prawem Bożym (Wyszyński 1946a, s. 3).

Dla kardynała Naród i rodzina to dwie rzeczywistości, które są ściśle od siebie uzależnione, to dwa określone i przypisane człowiekowi sposoby realizacji jego istnienia tu na ziemi. „Rodzina to fundament bytu narodowego, budowanie mocy i jedności narodu dokonuje się w rodzinie" (Wyszyński 1961a, s. 69). Kardynał Stefan Wyszyński nauczał: „Kto jest przyjacielem narodu - umacnia rodzinę, kto jest wrogiem narodu - niszczy rodzinę" (Wyszyński 1961b, s. 228).

Kardynał wiedział, że matki i ojcowie postawą swoją muszą dawać dowód wielkiej mądrości i mądrej polityki narodowej, która „umie pokornie wsiewać ziarno w pole i zbiera owoc z życia rodzinnego". Kardynał Stefan Wyszyński mówił do rodziców: „Musicie pokazać, że rozumiecie, iż naród rodziną żyje i przedłuża swój byt" (Wyszyński 1961, s. 229). Dlatego też ognisko domowe mają oni uświęcać nieustannie tak, aby było miejscem szacunku, miłości, a także odpoczynku dla siebie nawzajem (Wyszyński 1961, s. 39).

Ksiądz Prymas Stefan Wyszyński jako „głowa Kościoła katolickiego w Polsce od początku swego prymasowskiego posługiwania podejmował pedagogizację 
Narodu. Czynił to przez cały okres swej posługi kapłańskiej i prymasowskiej wychodząc z oryginalnej koncepcji pedagogiki społecznej, w myśl której Kościół jako społeczność ma prawo, możliwość i obowiązek wychowania nie tylko jednostek, lecz także całego Narodu chrześcijańskiego. Prymas czynił to, posługując się środkami zwyczajnego duszpasterzowania, jak również specjalnymi programami i dewocyjnymi formami pedagogizacji Narodu - podkreśla Alina Rynio (Rynio 2011, s. 250). Kardynał Wyszyński, pedagogizując Naród, kierował się duchem duszpasterskiej troski i uwzględniał konkretne zagrożenia, potrzeby czy błędne postawy. Oceniając konkretne sytuacje, uczył wyciągać wnioski na przyszłość. Naród w Jego nauczaniu i wyobrażeniu był nie tylko przedmiotem pedagogizacji, lecz także podmiotem wychowującym, bez udziału którego cały proces wychowania domagający się ram społecznych może się nie udać. Pojęcie Narodu jest budowane przez Prymasa na podobieństwo osoby - chrześcijanina, który ma ducha, ciało i łaskę (Rynio 2011, s. 250).

Należy pamiętać, że Naród, w imieniu którego przemawiał kardynał Wyszyński, jako Prymas i jako interrex, jest jednością - jak zauważa Piotr Mazurkiewicz: „Zawiera się w tym, jak się wydaje, pewien element ekskluzji w stosunku do tych, którzy nie spełniają kryteriów przynależności, jakimi są przede wszystkim katolicka wiara i identyfikacja z chwalebną przeszłością narodu. Można jednakże na to całościowe ujmowanie narodu spojrzeć również jako na rodzaj zamierzonej inkluzji. Prymas bowiem przemawiając $w$ imieniu narodu, nie tyle wyłączał ludzi niewierzących, co raczej - w pewnym sensie - włączał ich bez ich zgody. Przemawiając bowiem $w$ imieniu narodu, bronił również praw niekatolików i osób niewierzących" (Mazurkiewicz 2002, s. 275).

Natomiast obrona rodziny, a tym samym obrona Narodu, „polega także na odczytywaniu w życiu rodzinnym naturalnej, przyrodzonej wartości, to znaczy jej naturalnej radości. Prymas dostrzegał tę psychologiczną wartość, która jest niezmiernie ważna i nieustannie powinna być eksponowana, bo człowiek, mąż i żona oraz dzieci, bez tej radości tracą sens poniesionych nieustannych wysiłków, aby trwać w zjednoczonej rodzinie" (Struzik 2010, s. 110).

\section{Zakończenie}

Jakże aktualne pozostają treści nauczania kardynała Stefana Wyszyńskiego dotyczące Narodu, rodziny i rodzicielstwa. Warto je przypominać w obecnych czasach, kiedy ojcostwo i macierzyństwo jakże często pozostaje w kryzysie, kiedy współczesny człowiek błądzi po drogach teraźniejszego świata. Należy powracać do tych rozważań ukazujących prawdziwy model budowania rodziny, silnej Bogiem. Obecnie, kiedy podważa się sensowność sakramentalnych związków małżeńskich, kiedy publicznie nie używa się słów mąż, żona, tylko pseudo nowoczesne sformułowania partner, partnerka, potrzebujemy takich myśli - zdrowych, przemodlonych i zakorzenionych w nauce Kościoła. Prymas Wyszyński posiadał umiejętność 
odczytywania znaków czasu i perspektywicznego patrzenia. Wiedział, że Polska bez zdrowej rodziny straci swoją tożsamość i przekreślone zostaną dokonania Narodu i historia Ojczyzny, tak bardzo współistniejące z wiarą w Boga. Pamiętajmy, że wszystko, co nowe, a nie na Bogu zbudowane, nie ma trwałości.

\section{Bibliografia}

Karasiński W. (2002). Rodzina w świetle nauczania ks. Stefana Wyszyńskiego: na podstawie artykułów w „Ładzie Bożym” w latach 1945-196. „Studia Włocławskie”. T. 5, s. 337-344.

Kukołowicz T. (1982). O rodzinie w ujęciu kardynała Stefana Wyszyńskiego Prymasa Polski. „Ład Boży”, nr 1.

Lewandowski J. (1983). Naród w nauczaniu kardynała Stefana Wyszyńskiego. „Chrześcijanin w Świecie", nr 116.

Libersat H. (1995). Rodzice chrzestni. Toruń: Christ Book, Nazaret.

Mazurkiewicz P. (2002). Teologizacja narodu czy nacjonalizacja Kościoła?: koncepcja narodu w nauczaniu kardynała Stefana Wyszyńskiego. „Seaculum Christianum”, nr 9/2, s. $267-276$.

Mierzwiński B. (1996). Mężczyzna, mąż, ojciec. Otwock: Edycja św. Pawła.

Rosik S. (1991). Promocja aksjologicznej pozycji osoby ludzkiej i wspólnoty rodzinnej w niektórych dziełach kard. Stefana Wyszyńskiego. „Roczniki Teologiczne”. T. XXXVIIIXXXIX, z. 3.

Rynio A. (2011). Mądre wychowanie patriotyczne przedmiotem troski Prymasa Tysiaclecia. „Studia Prymasowskie”. T. 5, s. 247-264.

Skreczko A. (2006). Rodzicielstwo jako dar i zadanie na podstawie nauczania prymasa Stefana Wyszyńskiego podczas wielkiej nowenny tysiaclecia. „Rocznik Teologii Katolickiej”. T. 5, s. 145-183.

Struzik Z. (2010). Rodzina Bogiem silna moca swego narodu. Nauczanie o rodzinie kard.

S. Wyszyńskiego. Warszawa: „Kultura-Media-Teologia”, nr 3, s. 105-119.

Wojtyła K. (1986). Miłość i odpowiedzialność. Lublin: Towarzystwo Naukowe KUL.

Wyszyński S. (1946a). Pomoc społeczna małżonkom. Włocławek. „Ład Boży”, nr 23.

Wyszyński S. (1946b). Współdziałanie Kościoła i państwa na rzecz małżeństwa. Włocławek. „Ład Boży”, nr 24.

Wyszyński S. (1958). Droga Krzyżowa pracowników pióra. Jasna Góra, 4.05.1958. W: Wyszyński S. Kazania i przemówienia autoryzowane przez Prymasa Polski. Zbiór maszynopisów zgromadzonych $w$ Instytucie Prymasowskim w Warszawie (mps, dalej skrót: KPAM). T. 4.

Wyszyński S. (1959). Do katolickich wychowawców i nauczycieli. Jasna Góra, 19.04.1959. W: KPAM. T. 5

Wyszyński S. (1960). Dziękczynienie Bogu za Matkę Bożą. Bydgoszcz, 11.09.1960. W: KPAM. T. 7.

Wyszyński S. (1961a). Rodzice! Nadeszła Wasza godzina. Jasna Góra, 15.08.1961. W: KPAM. T. 9. 
Wyszyński S. (1961b). Rodzina Bogiem silna. Jasna Góra, 26.08.1961. W: KPAM. T. 9.

Wyszyński S. (1961c). Rodzina Bogiem silna. Warka, 7.05.1961. W: KPAM. T. 8.

Wyszyński S. (1962). Humanistyczne wartości Bożego Narodu. Warszawa, 8.01.1962.

W: KPAM. T. 3.

Wyszyński S. (1963a). Do Mego Ojca. Warszawa, 1.04.1963.W: KPAM. T. 14.

Wyszyński S. (1963b). Orędzie Biskupów Polskich do kapłanów i wiernych o prawic do nauczania religii. 22.09.1963. W: KPAM. T. 15.

Wyszyński S. (1963c). W Hołdzie Pocieszycielce ziemi nowosadeckiej. Zawada, 25.08.1963.

W: KPAM. T. 15.

Wyszyński S. (1964). Spokojni o chleb dla licznych ust. Inowłódz, 23.08.1964. W: KPAM. T. 18. Wyszyński S. (1965). List Pasterski Biskupów polskich o Polskiej Rodzinie Katolickiej. 10.01.1965. W: KPAM. T. 19.

Wyszyński S. (1966). Co Kościół daje Narodowi w wiary nowym tysiącleciu? Opole, 14.08.1966. W: KPAM. T. 24.

Wyszyński S (1995). Przyrzekamy toczyć bój z naszymi wadami narodowymi. Kazanie na pierwsza sobotę kwietnia [1957]. Komańcza, wrzesień 1956. W: Wyszyński S. Dzieła zebrane. T. 2: 1953-1956. Warszawa: Wydawnictwo im. S. kard. Wyszyńskiego „Soli Deo”. Wyszyński S. (1998). Jedna jest Polska. Wybór z przemówień i kazań. Warszawa: Wydawnictwo im. Stefana kard. Wyszyńskiego „Soli Deo”.

Wyszyński S. (1999a). Nie pozwolimy znieważać naszych świętości. Przemówienie do Warszawskiej Pielgrzymki na Jasną Górę. Warszawa, kościół Świętego Ducha, 6.08.1957. W: Wyszyński S. Dzieła zebrane. T. 3: 1956-1957. Warszawa: Wydawnictwo im. S. kard. Wyszyńskiego „Soli Deo”.

Wyszyński S. (1999b). Kazanie na uroczystość Świętej Rodziny. Warszawa, kościół Świętego

Michała, 13.01.1957. W: Wyszyński S. Dzieła zebrane. T. 3: 1956-1957. Warszawa:

Wydawnictwo im. S. kard. Wyszyńskiego „Soli Deo”.

Wyszyński S. (1999c). Rodzice, nadeszła wasza godzina. Kazanie do małżonków katolickich.

Gniezno, Bazylika Prymasowska, 15.08.1957. W: Wyszyński S. Dzieła zebrane. T. 3: 1956-1957. Warszawa: WSD.

Wyszyński S. (1999d). To jest nasz program prymasowski. Gniezno, 2.02.1957.

W: Wyszyński S. Dzieła zebrane (dalej skrót: DZ). T. 3, Warszawa: Wydawnictwo im.

S. kard. Wyszyńskiego „Soli Deo”, s. 138.

Wyszyński S. (1999e). Witaj Jezu, Synu Maryi. Warszawa, 20.06.1957. W: DZ. T. 3.

Wyszyński S. (1999f). Przez wodę i krew do Tysiąclecia Chrztu Polski. Gniezno, 28.04.1957.

W: DZ. T. 3.

Wyszyński S. (1999g). Rodzice nadeszła wasza godzina. Gniezno, 15.08. 1957. W: DZ. T. 3. Wyszyński S. (1999h). Narodowy ciężar Ślubowań Jasnogórskich poniesiemy z Maryją. Jasna Góra, 3.05.1957. W: DZ. T. 3.

Wyszyński S. (2007a). Do górali tatrzańskich. Zakopane, kościół parafialny, 19.08.1957.

W: KiPA. T. 2.

Wyszyński S. (2007b). Jasnogórskie zobowiązania. Bydgoszcz, 19.12.1956. W: KiPA. T. 1. 
Wyszyński S. (2007c). Kazanie na uroczystość Świętej Rodziny. Warszawa, kościół Świętego Michała, 13.01.1957. W: KiPA. T. 2.

Wyszyński S. (2007d). Kazanie na uroczystość Świętej Rodziny. Warszawa, kościół Świętego Michała, 13.01.1957. W: Wyszyński S. Kazania i przemówienia autoryzowane przez samego autora (dalej skrót: KiPA). T. 2.

Wyszyński S. (2007e). Każdy kapłan pracuje nad wprowadzeniem w życie Ślubów Jasnogórskich. Apel do duchowieństwa. Komańcza, sierpień 1956. W: KiPA. T. 1.

Wyszyński S. (2007f). Tych Dwoje nadzieja narodu iświata. Słowo do rodzin zebranych na „Opłatku”. Gniezno, 1968. W: KiPA. T. 28.

\title{
EDUCATIONAL VALUE OF TEACHING BL. STEFAN CARDINAL WYSZYŃSKI ABOUT FAMILY AND NATION
}

\begin{abstract}
The Blessed Cardinal lost his mother at the age of nine, since then his Mother became the Motherland for which he served, loved and fought for - he used love to every neighbour to fight and he fought for every one of them. He experienced the atrocities of the war and the Soviet regime, his beloved Homeland deprived him of his freedom, and he arranged the Jasna Góra Vows for her, which became the first step on the way to liberate the homeland, nation and Polish family, for which Cardinal Wyszyński was the undisputed father.
\end{abstract}

Keywords: Stefan Cardinal Wyszyński, Family, Nation, Mother, Father, Upbringing, Faith. 